\title{
Communication Strategy of the Indonesian Ministry of Religion to Leave 20 Countries that Area Prohibited from Entering Saudi Arabia
}

\section{Junaidi}

\section{INSTITUTION}

Universitas Sahid Jakarta

Indonesia

\section{PHONE}

o811753750

\section{EMAIL}

junaidisjpku@gmail.com

\section{DOI}

https://www.doi.org/

10.37010/prop.v2i1.445

\section{PAPER PAGE}

51-64

PROPAGANDA is a

Journal of Communication Studies which is publish twice a year on January and July. PROPAGANDA is a scientific publication media in the form of conceptual paper and field research related to communication studies. It is hoped that PROPAGANDA can become a media for academics and researchers to publish their scientific work and become a reference source for the development of science and knowledge.

\author{
Strategi Komunikasi Kementerian Agama Indonesia Agar \\ Keluar dari 20 Negara yang Dilarang Masuk Arab Saudi
}

\begin{abstract}
Keputusan pemerintah Saudi untuk menutup akses bagi Indonesia untuk diperkenankan masuk wilayahnya menjadikan Indonesia untuk kali kedua batal melakukan ibadah tahunan yaitu ibadah haji. Penelitian ini bertujuan untuk mengetahui dan mendeskripsikan strategi komunikasi Kementerian Agama (Kemenag) agar Indonesia tidak termasuk 20 negara yang dilarang memasuki Arab Saudi. Karena beberapa negara yang memiliki angka Covid-19 lebih tinggi atau sama dengan Indonesia tidak masuk 20 negara yang dilarang. Sejauh Mana strategi komunikasi yang dibangun Kemenag dalam rangka meyakinkan Arab Saudi bahwa penerapan protokol kesehatan Indonesia sangat ketat. Apakah kebijakan-kebijakan Kementerian Agama RI sejalan dengan kebijakan Pemerintah Arab Saudi. Penelitian ini juga mengambil sampel beberapa pemberitaan menurut kacamata media/framing media dari Republika.co.id dan beberapa berita dari media lainnya yang sesuai kaitannya untuk menjawab penelitian ini. Penelitian ini menunjukkan bahwa kebijakan dan strategi komunikasi Kementerian Agama belum melibatkan secara optimal kelompok civil society. Serta strategi komunikasi yang dibangun pemerintah dan organisasi tidak memperlihatkan kepentingan terogranisir yang baik.

The Saudi government's decision to close access for Indonesia to be allowed to enter its territory made Indonesia for the second time cancel its annual pilgrimage, namely the pilgrimage. This study aims to identify and describe the communication strategy of the Ministry of Religion (Kemenag) so that Indonesia is not included in the 20 countries that are prohibited from entering Saudi Arabia. Because some countries whose COVID-19 numbers are higher or equal to Indonesia are not included in the 20 banned countries. To what extent is the communication strategy developed by the Ministry of Religion in order to convince Saudi Arabia that the implementation of Indonesian health protocols is very strict. Are the policies of the Ministry of Religion of the Republic of Indonesia in line with the policies of the Government of Saudi Arabia. This study also took samples of several news reports according to media/media framing from Republika.co.id and several news stories from other media that were relevant to answer this research. This study shows that the Ministry of Religion's communication policies and strategies have not optimally involved civil society groups. And the communication strategy developed by the government and organizations does not show good organized interests.
\end{abstract}

\section{KEYWORD}

strategi komunikasi, pembingkaian, haji, kementerian, umrah

communication strategies, framing, hajj, ministries, umrah 


\section{PROPAGANDA}

\section{PENDAHULUAN}

Masalah serius yang kini tengah dialami oleh masyarakat internasional adalah Virus yang bernama Covid-19. World Health Organization (WHO) sebagai lembaga tata kelola kesehatan global yang diakui secara umum di dunia telah menetapkan penyakit Covid-19 sebagai penyakit level pandemi, hal ini dikemukakan oleh Dirjen WHO, Dr. Tedros Adhanom Ghebreyesus (Widyaningrum, 2020). Ini artinya penyebaran virus ini merupakan penyakit yang menular dan harus mendapatkan perhatian serta penanganan yang serius baik itu dari sistem tata kelola kesehatan global, Negara, bahkan individu masyarakat.

Dunia tidak lagi sama akibat Covid-19. Sebagaimana pandemi yang pernah melanda, Covid-19 mendorong terjadinya banyak perubahan dan telah melahirkan norma dan praktik baru dalam tatanan sosial, politik dan ekonomi; baik pada level individu, komunitas, kelembagaan dan hubungan antar bangsa (Copenhagen Economics, 2020). Misalnya, menghadirkan analisis kemunduran globalisasi sebagai akibat menguatnya pendekatan nasionalis dalam menangani pandemi dan kecenderungan self sufficiency. Situasi yang disebut dengan the reversing of globalization ini menjadi salah satu normalitas baru dalam hubungan antar bangsa sebagai dampak Covid-19 (Mas'udi dan Winanti, 2020).

Tarik ulur antara kepentingan ekonomi dan kesehatan sudah berlangsung sejak merebaknya Covid-19. Pilihan yang berlangsung cenderung bersifat zero-sum, yang melihat kedua kepentingan tersebut saling berseberangan dan meniadakan satu sama lain (Lin dan Meissner, 2020). Melihat penjelasan yang demikian menggambarkan bahwa Covid-19 merupakan penyakit yang mampu mengubah segalanya dalam sekejap. Selain Covid-19 menular dan telah dikategorikan sebagai pandemi tentunya hal tersebut membuat berbagai Negara di dunia bergerak untuk melakukan upaya apa pun untuk meminimalisasi penyebaran Covid-19 di negaranya masing-masing. Dengan berbagai kebijakan yang diberlakukan untuk menghindari tiap-tiap Negara agar terhindar dari penyebaran kasus penyakit seperti Covid-19.

Jika tidak ditangani, hal ini bisa menjadi sebuah konflik vertikal antar masyarakat dengan pemerintah, di mana konflik vertikal ini memerlukan sebuah komunikasi yang intens untuk menyelesaikannya (Bakti, 2000). Tidak banyak penelitian yang membahas soal Covid19 di Arab Saudi, salah satunya adalah penelitian tentang judul Covid-19 social distancing in the Kingdom of Saudi Arabia: Bold Measures in the Face of Political, Economic, Social and Religious Challenges, karya tulis Saber Yezli dan Anas Khan. Penelitian ini membahas social distancing sebagai langkah utama yang harus diambil untuk menangani dan mengurangi transmisi Covid-19 terutama di Negara Arab Saudi yang dikenal sebagai Negara agamis.

Selain itu, dengan berani Arab Saudi mengambil tindakan dengan melakukan kebijakan penutupan segala kegiatan akses publik seperti kegiatan olahraga. Termasuk yang paling berani memberikan kebijakan penutupan akses ibadah di masjid dan kegiatan ibadah yang melibatkan umat agama dari luar negeri seperti umrah sebagai upaya penanganan masalah penyebaran penyakit menular (Yezli dan Khan, 2020).

Pada Maret 2020 lalu, terdapat 50 negara yang warganya dilarang datang ke Arab Saudi untuk sementara demi mencegah penyebaran virus korona Covid-19. Negara tersebut ialah Austria, Bahrain, Belanda, Belgia, Bulgaria, Ceko, China, Denmark, Djibouti, Eritrea, Estonia, Ethiopia, Finlandia, Hongaria, India, Indonesia, Irak, Iran, Italia, Jerman, dan Kenya.

Selain itu larangan yang sama untuk menegah meluasnya virus korona Covid-19 juga ditujukan bagi warga Korea Selatan, Kroasia, Kuwait, Latvia, Libanon, Lithuania, Luxembourg, Malta, Mesir, Oman, Pakistan, Prancis, Polandia, Portugal, Rumania, Siprus, Slovakia, Slovenia, Somalia, Spanyol, Sri Lanka, Sudan, Sudan Selatan, Suriah, Swedia, Swiss, Turki, Uni Emirat Arab, dan Yunani. Pemerintah Arab Saudi melarang sementara masuknya individu dari negara-negara tersebut karena khawatir terjadi penularan virus korona Covid-19 dari negara-negara itu. 
Pada akhir 2020, Arab Saudi mulai membuka akses bagi beberapa negara termasuk Indonesia. Jamaah umrah Indonesia diperbolehkan masuk ke Arab Saudi dengan penerapan protokol kesehatan yang ketat. Selama masa proses dibukanya akses masuk ini, banyak terjadi persoalan dan yang paling mendasar ialah masalah komunikasi.

Akhirnya, Pemerintah Arab Saudi kembali memberlakukan kebijakan baru untuk menekan laju pertumbuhan virus korona di negaranya. Diberitakan Reuters, Rabu (3/2/2021), Arab Saudi mulai menangguhkan masuknya orang-orang ke kerajaan dari 20 negara pada Selasa (2/2/2021). Larangan masuk sementara itu berlaku mulai 3 Februari, termasuk orangorang yang datang dari Uni Emirat Arab, Jerman, Amerika Serikat, Inggris, Afrika Selatan, Perancis, Mesir, Lebanon, India, dan Pakistan. (Artikel ini telah tayang di Kompas dengan judul "Arab Saudi Blokir Masuknya Warga 20 Negara Termasuk Indonesia Mulai 3 Februari.) Ke 20 negara yang dilarang masuk sementara itu ialah Indonesia, Uni Emirat Arab, Argentina, Jerman, Amerika Serikat, Britania, Afrika Selatan, Perancis, India, Pakistan Mesir, Libanon, Irlandia, Italia, Brazil, Portugal, Turki, Swedia, Swiss, Jepang.

Meski larangan masuk bersifat sementara, tapi kementerian tidak menjelaskan kapan penangguhan itu akan dicabut. Keputusan untuk menangguhkan masuknya warga dari 20 negara tersebut datang pada hari yang sama ketika Kerajaan mencatat empat kematian baru terkait Covid-19 pada Selasa, menjadikan total korban tewas menjadi 6.366.

Selain langkah berani yang telah diterapkan oleh Arab Saudi, Negara yang menjadi kiblat umat Islam tersebut juga mengumumkan bahwa Arab Saudi mengeluarkan larangan masuk bagi 20 warga negara salah satunya adalah Indonesia, yang diumumkan pada 2 Februari 2021. Tentu saja, dengan adanya pelarangan ini mengundang keprihatinan bagi Indonesia, pasalnya ini merupakan larangan ke dua kalinya untuk warga Indonesia melaksanakan ibadah haji dan umrah di tanah suci.

Meski mendapat larangan tersebut, Kepala Bidang Umrah Asosiasi Muslim Penyelenggara Haji dan Umrah Republik Indonesia mendukung penuh keputusan pemerintah Arab Saudi dan dapat berdampak baik bagi semua orang. Dikutip dari laman SampaiJauhcom, Tercatat, kasus positif Covid-19 di Indonesia pada Selasa, 2 Februari 2021 sebanyak 1.099.687 kasus dengan 896.530 pasien berhasil sembuh. Sedangkan kasus meninggal 30.581 orang, dengan begitu total kasus aktif masih terinfeksi Covid-19 sebanyak 172.576 orang.

Selain itu, Duta Besar Indonesia untuk Arab Saudi Agus Maftuh Abegebriel mengatakan ada beberapa alasan terkait larangan masuk dari 20 negara, termasuk Indonesia yang diberlakukan oleh Arab Saudi. Salah satunya, adanya perhatian yang sangat luar biasa terhadap pandemi virus Covid-19 di dunia. Kedua, Arab Saudi ingin mendahulukan, memprioritaskan kesehatan publik di Kerajaan Arab Saudi (Aivanni, 2021).

Dari beberapa penelitian yang telah penulis baca mengenai kebijakan yang diambil Negara dalam pengamanan Covid-19 terutama di Arab Saudi. Penulis memutuskan untuk meneliti framing media terkait Strategi Komunikasi Kementerian Agama Indonesia Agar Keluar dari 20 Negara yang Dilarang Masuk Arab Saudi. Padahal Indonesia dengan Arab Saudi dinilai memiliki hubungan yang kokoh. Karena kedua Negara tersebut memiliki komitmen yang sama untuk terus meningkatkan kerja sama di berbagai sektor kehidupan, sehingga dapat memformulasikan sebuah kerja sama yang kongkret (Misrawi, 2021).

Ada dua esensi framing utama, yakni bagaimana peristiwa dimaknai dan bagaimana fakta ditulis. Analisis framing merupakan metode analisis teks sebagaimana analisis isi kuantitatif, namun keduanya mempunyai perbedaan karakteristik. Dalam analisis isi kuantitatif yang ditekankan adalah isi dari suatu pesan/teks komunikasi. Sementara pusat perhatian analisis framing adalah pembentukan pesan/makna dari teks. Framing melihat bagaimana teks/pesan dikonstruksi oleh wartawan dan media serta bagaimana menyajikannya kepada khalayak (Sobur, 2002:162). Maka dari itu framing sangat pas untuk meneliti terkait strategi kementerian agama. 


\section{PROPAGANDA}

\section{METODE}

Dalam penelitian ini, jenis penelitian yang penulis gunakan adalah penelitian kualitatif yang bersifat deskriptif-kualitatif. Metode deskriptif pada suatu penelitian tidak mencari hubungan, tidak menguji hipotesis ataupun membuat prediksi (Rachmat, 2004). Metode ini memiliki titik berat pada observasi dan suasana alamiah, dalam hal ini peneliti bertindak sebagai pengamat. Sedangkan metode kualitatif merupakan metode penelitian yang digunakan untuk meneliti obyek yang alamiah, di mana pada metode ini penulis sebagai instrumen kunci. Teknik pengumpulan data dapat dilakukan secara triangulasi (gabungan), analisis data bersifat induktif atau kualitatif, dan hasil penelitian ini akan lebih menekankan makna dari pada generalisasi (Sugiyono, 2014).

Analisis data adalah proses mencari dan menyusun secara sistematis data yang diperoleh dari hasil wawancara, catatan lapangan, dan bahan-bahan lain sehingga mudah dipahami dan temuannya dapat diinformasikan keadaan orang lain. analisis data dilakukan dengan cara mengorganisasikan data ke dalam kategori, menjabarkan ke dalam unit-unit, melakukan sintesa, menyusun ke dalam pola, memilih mana yang penting dan yang akan dipelajari, dan membuat kesimpulan sehingga mudah dipahami oleh diri sendiri maupun orang lain (Sugiyono, 2012:.224)

Framing dapat membentuk rekayasa opini publik tentang suatu kasus. Dengan mempertajam frame tertentu tentang sebuah isu, mereka dapat mengklaim bahwa opini publik yang berkembang mendukung kepentingan mereka, atau konvergen dengan "klaim kebenaran" mereka. Realitas dan peristiwa itu begitu kompleks dan acak, ia harus diidentifikasi (diberi nama, diidentifikasi dan dihubungkan dengan peristiwa lain yang diketahui oleh khalayak) dan ditempatkan dalam konteks sosial tertentu di mana khalayak tersebut berada (sering kali itu dilakukan dengan menempatkan peristiwa dalam kerangka acuan yang familier dari khalayak) (Eriyanto, 2005: 119).

Selain menggunakan metode deskriptif kualitatif, penelitian ini juga menggunakan teori framing. Di mana framing adalah bagaimana cara jurnalis melaporkan sebuah peristiwa berdasarkan sudut pandang yang ingin disampaikan kepada khalayak pembaca. Pada proses penyeleksian itu, tidak semua fakta yang didapat wartawan dituangkan mentah-mentah pada suatu berita. Namun, ada fakta yang sengaja ditonjolkan, tapi ada juga fakta yang sengaja diembargo. Semua itu tergantung dengan apa yang ingin disampaikan pada pemberitaan tersebut.

Melalui analisis framing, akan diketahui siapa mengendalikan siapa, siapa lawan siapa, mana kawan mana lawan, mana patron dan mana klien, siapa diuntungkan dan siapa dirugikan, siapa menindas dan siapa tertindas, dan seterusnya. Kesimpulan-kesimpulan seperti ini sangat mungkin diperoleh karena analisis framing merupakan suatu seni-kreativitas yang memiliki kebebasan dalam menafsirkan realitas dengan menggunakan teori dan metodologi tertentu.

Seperti pemaparan di atas, maka peneliti memilih berita yang diterbitkan Republika.co.id dengan memilih beberapa berita yang sesuai dan memiliki kaitan dengan tema yang tengah diteliti. Berikut berita yang telah dipilih :

Tabel 1. Berita Republika.co.id

\begin{tabular}{ll}
\hline & \multicolumn{1}{c}{ Republika.co.id } \\
\hline Data & Judul Berita \\
\hline 1. & 11 negara Diizinkan Kembali Masuk ke Saudi, Indonesia? \\
2. & Pemerintah Rancang Kebijakan Ibadah Haji di Tengah Pandemi \\
3. & Kemenag : Pemerintah Intensif Diplomasi Arab Saudi \\
\hline Sumber: & Diolah (2021)
\end{tabular}


Diketahui bersama, pada tahun lalu, pemerintah Arab Saudi memutuskan untuk melarang Indonesia masuk ke wilayah Arab Saudi. Adapun jemaah yang diizinkan naik haji tahun lalu adalah ekspatriat yang bermukim di sana dan penduduk lokal. Sebelumnya Arab Saudi dilaporkan tengah mempertimbangkan untuk melarang kembali jemaah haji dari luar ini negeri karena peningkatan kasus Covid-19 secara global.

Bermula dari wabah yang mengancam keselamatan manusia, Covid-19 turut meruntuhkan struktur ekonomi yang berjalan normal selama beberapa dekade terakhir (ILO, 2020). Dalam laporannya menyebut bahwa pandemi Covid-19 memberi dampak yang hebat dan berkepanjangan pada aktivitas ekonomi. Ketenagakerjaan, dan perdagangan. Berdasarkan prediksi (IMF, 2020) dalam outlook bertajuk "A Crisis Like No Other, An Uncertain Recovery", dikatakan bahwa pertumbuhan ekonomi Indonesia akan turun mencapai titik terendah pascakrisis ekonomi 1998, yaitu minus 0,3\%. Yang paling sering terjadi konflik di Indonesia adalah soal isu agama. Meski agama memiliki hubungan yang cukup erat dengan etnik. Akan tetapi agama juga bisa saja memunculkan disintegrasi. Semuanya berakibat dari integrasi. Juga yang menomorsatukan salah satu etnis saja (Bakti, 2008). Hal ini juga berkaitan dengan roda bola pasar yang sangat diperlukan bagi setiap Negara (Bakti, 2006).

Berdasarkan paparan di atas, maka Objek penelitian ini adalah fokus terhadap larangan haji dan umrah di masa pandemi yang menjadi keputusan pemerintah Indonesia khususnya kebijakan dari kementerian agama.

Dalam penelitian mengenai pembingkaian berita Strategi Komunikasi Kementerian Agama Indonesia Agar Keluar dari 20 Negara yang Dilarang Masuk Arab Saudi, peneliti ingin meneliti bagaimana framing media terkait strategi kementerian agama. Hal ini disebabkan isi berita dapat mencerminkan konstruksi realitas dan ideologi yang dimiliki oleh media. Oleh sebab itu, pendekatan kualitatif merupakan pendekatan yang paling tepat untuk digunakan dalam penelitian ini. Di mana menekankan tentang analisis framing oleh suatu media mengenai sebuah kasus. Pendekatan kualitatif dilakukan untuk meneliti pembingkaian yang dilakukan oleh media terkait strategi kementerian agama.

\section{HASIL DAN PEMBAHASAN}

Penanganan kesehatan merupakan hal yang paling penting guna mengantisipasi penyebaran Covid-19. Namun begitu, Covid-19 juga memiliki dampak turunan yang tidak kalah besarnya. Seperti dikutip dari majalah Etika (Dewan Pers, 2020) bahwa: "yang dibutuhkan saat ini tidak pada sebatas penanganan medis terhadap masyarakat yang terpapar atau diduga terpapar virus korona, tetapi juga dampak turunan pandemi Covid-19”.

Salah satu dampak turunan Covid-19 adalah pelaksanaan ibadah, termasuk juga ibadah haji dan umrah, yang mulanya pada tahun 2020 lalu Pemerintah Kerajaan Arab Saudi tepatnya pada 22 Juni 2020 mengumumkan secara resmi bahwa ibadah haji tetap diselenggarakan dengan pembatasan secara ketat, mulai dari jemaah haji, usia, kondisi kesehatan dan jemaah yang khusus mereka yang sudah berada di Arab Saudi dalam kurun waktu tertentu (Mabruroh, 2020).

Tahun 2021 ini pemerintah Arab Saudi kembali melakukan kebijakan dengan memperketat penerimaan Jemaah haji. Hal ini pun berdampak pula dengan ke tidak bagiannya Indonesia sebagai salah satu Negara yang masuk ke dalam Negara yang dilarang untuk melakukan ibadah haji dan umrah di Arab Saudi. Dengan demikian, dua tahun berturut-turut tak ada Jemaah haji asal Indonesia yang diberangkatkan ke tanah suci dalam ibadah tahunan ini.

Strategi komunikasi yang dilakukan Kementerian Agama agar Indonesia tidak termasuk 20 negara yang dilarang untuk masuk Arab Saudi dengan melakukan beberapa 


\section{PROPAGANDA}

tindakan seperti yang kita ketahui sebelumnya bahwa Indonesia kini terus melakukan kerja sama Internasional dalam pengadaan vaksin Covid-19. Setelah melobi China hingga Amerika Serikat (AS) untuk mendapatkan vaksin, kini giliran Arab Saudi. Berbeda dari sebelumnya, lobi yang dilakukan ke Arab Saudi kali ini terkait persyaratan umrah dan haji. Indonesia mau Arab Saudi mengizinkan vaksin Sinovac dipakai para Jemaah.

Maraknya virus Covid-19 yang semakin menjadi yang pada akhirnya membuat rapat terbatas di mana presiden berkoordinasi dengan para menterinya dilakukan secara rutin seminggu sekali. (Maharani, 2020). Dikutip dari Tempo.co bahwa Menteri Agama Yaut Cholil Qoumnas dalam konferensi pers di Kantor Kementerian Agama mengatakan seperti kutipan berikut.

Menetapkan pembatalan keberangkatan haji pada penyelenggaraan ibadah haji $1442 \mathrm{Hatau}$

2021 bagi warga Negara Indonesia yang menggunakan kuota haji Indonesia dan kuota haji lainnya.

Keputusan tersebut juga telah berdasarkan pada sejumlah kajian yang dilakukan. Kemenag juga melakukan komunikasi dengan berbagai pihak, termasuk komisi 8 DPR RI. Bahkan Kementerian Agama telah melakukan komunikasi intensif dengan Kementerian Haji Arab Saudi.

Sebelumnya Pemerintah Arab Saudi hanya memberikan izin warga yang sudah di vaksin penuh untuk masuk negaranya. Alasannya, untuk mencegah penyebaran Covid-19. Namun, tidak semua vaksin yang diakui Arab Saudi. Pemerintah Arab Saudi hanya menerima vaksin Pfizer, AstraZeneca, Moderna, dan Johnson N Johnson

Anggota DPR RI, Nuson Wahid juga meminta kepada pemerintah agar berupaya mendapat sertifikat WHO untuk vaksin Sinovac. Hal itu dilakukan agar Jemaah haji Indonesia yang sudah di vaksin dapat lolos persyaratan untuk menjalankan ibadah haji di tanah suci.

Indonesia termasuk Sembilan Negara yang masih ditangguhkan masuk Arab Saudi. Penangguhan itu dikeluarkan sejak 29 Mei 2021 sampai batas waktu yang belum ditentukan. Meski kebijakan Negara bersifat sementara dan disesuaikan dari waktu ke waktu. Namun pemerintah tetap harus selalu memperhatikan kebijakan yang dikeluarkan Arab Saudi agar Indonesia bisa keluar dari 20 negara yang dilarang masuk ke Arab Saudi

Adapun pengamat haji dan umrah dari UIN Syarif Hidayatullah Jakarta, Dadi Damardi, mengingatkan pemerintah agar memastikan bahwa Jemaah haji tahun ini dapat berangkat tahun depan. Sementara itu pengusaha dan asosiasi penyelenggaran haji dan umrah berharap agar pemerintah mempertimbangkan untuk dapat membuka pintu haji khusus.

Hal ini harus dibarengi dengan keseriusan Pemerintah Indonesia dalam menangani Covid-19. Indonesia harus keluar dari daftar 20 negara yang dilarang terbang tersebut. Apalagi ketika umrah bagi Jemaah asing dibuka tahun lalu, jamaah Indonesia mendapat prioritas utama.

Alasan lainnya mengapa Indonesia masih masuk ke dalam 20 negara yang dilarang jika dibandingkan dengan Negara lain yang memiliki angka Covid-19 sama dengan Indonesia bahkan ada pula yang lebih tinggi angka penyebarannya namun diperbolehkan untuk memasuki wilayah Arab Saudi. Kementerian Agama, Yaqut Cholil Qoumnas menghimpun beberapa alasan Indonesia membatalkan keberangkatan Jemaah haji 2021, yaitu:

1. Arab Saudi belum hubungi Pemerintah Indonesia. Yaqut mengungkapkan, hingga saat ini pemerintah Arab Saudi belum mengundang pemerintah Indonesia untuk membahas dan menandatangani Nota Kesepahaman tentang persiapan penyelenggaraan ibadah haji 2021. Bahkan dirinya juga mengungkapkan hal tersebut juga berlaku di semua Negara.

2. Segala persiapan haji belum rampung. Sulitnya penerapan protokol kesehatan, penerapan yang diberlakukan Arab Saudi diberlakukan dengan sangat ketat. Hal itulah juga yang menjadi sebuah pertimbangan.

3. Keputusan berlaku untuk semua WNI, baik dengan kuota haji Indonesia maupun kuota haji lainnya 
4. Sudah dilakukan pembahasan mendalam. Masih tingginya kasus Covid-19, pemerintah menilai bahwa pandemi Covid-19yang masih melanda hampir seluruh Negara di dunia, termasuk Indonesia dan Arab Saudi yang dapat mengancam keselamatan Jemaah

5. Pastikan Jemaah yang batal haji tahun ini berangkat 2022. Persilakan Jemaah ambil uang haji, namun mematikan bagi calon Jemaah yang tidak mengambil kembali setorannya untuk dipergunakan tahun depan tersimpan aman (Prastiwi, 2021).

Pemerintah Arab Saudi, dikutip dari laman Saudigazette, menyatakan akan membolehkan jemaah haji internasional datang dan beribadah. Sejauh ini belum ada keputusan resmi mengenai jumlah dan tata cara yang harus dilakukan agar ibadah haji kali ini berlangsung. Namun, berdasarkan informasi yang didapat Asosiasi Muslim Penyelenggara Haji dan Umrah RI (Amphuri), pemerintah Arab Saudi memberikan kuota 45.000 anggota Jemaah internasional dan 15.000 anggota Jemaah lokal Arab Saudi pada penyelenggaraan haji 2021. Jika merujuk dari angka tersebut pada kuota reguler Indonesia yang lebih kurang 8-10 persen dari total Jemaah haji, kemungkinan Indonesia hanya bisa memperoleh kuota sekitar 5.000 anggota Jemaah.

Pada akhirnya, pemerintah Arab Saudi mencabut larangan pelancong yang datang dari 11 negara yang diberlakukan untuk penyebaran Covid-19. Arab Saudi sebelumnya telah menangguhkan masuk 20 negara pada 3 Februari 2021, termasuk Pakistan dengan pengecualian diplomat, warga Negara Saudi, praktisi medis dan keluarga mereka untuk membantu mengekang penyebaran Covid-19. Larangan juga diberlakukan untuk Mesir, UEA, Lebanon, Turki, Inggris, Prancis, Jerman, Irlandia, Italia, Portugal, Swedia, Swiss, AS, Argentina, Brasil, Pakistan, India, Indonesia, Jepang dan Afrika Selatan. Kedutaan besar kerajaan Arab Saudi juga telah menulis surat kepada Kementerian Luar Negri tentang masalah itu (Putra, 2021).

Uni Emirat Arab, Jerman, Amerika Serikat, Irlandia, Italia, Portugal, Inggris, Swedia, Swiss, Prancis dan Jepang merupakan 11 negara yang akhirnya diperbolehkan masuk Arab Saudi mulai 30 Mei 2021. Meskipun ada syarat khusus seperti melakukan karantina saat pertama datang. Indonesia sampai saat ini tidak masuk ke dalam 11 negara yang di perolehkan datang ke Arab Saudi.

Meski demikian, hal tersebut tetap tidak membuat Indonesia keluar dari 20 nama Negara yang dilarang. Bahkan baru-baru ini terdapat 11 negara yang dikatakan pihak Arab Saudi akan mengizinkan serta mencabut larangan untuk masuk ke wilayahnya. Dilansir dari Arab News, Minggu (30/5), sebelas Negara yang kini bebas keluar masuk kerajaan Saudi adalah UEA, Jerman, AS, Irlandia, Italia, Portugal, Inggris, Swedia, Swiss, Jepang dan Prancis.

Pihak berwenang disebut memindahkan mereka dari daftar merah karena upaya Negara untuk mengendalikan pandemi Covid-19 di wilayahnya.

Duta Besar Indonesia untuk Arab Saudi Agus Maftuh Abegebriel mengatakan ada dua alasan terkait larangan masuk dari 20 negara termasuk Indonesia yang diberlakukan Arab Saudi. Pertama, adanya perhatian yang sangat luar biasa terhadap pandemi Covid-19 di dunia. Baru-bau ini pemerintah telah merancang kebijakan ibadah haji di tengah pandemi. Hal tersebut tentunya membawa angina segar bagi masyarakat Indonesia agar Indonesia bebas dari larangan yang diberlakukan Arab Saudi.

Tentu kami tidak hanya ingin memberikan kenyamanan dan keamanan jamaah, dengan menyiapkan makanan dan pesawat yang bagus. Tetapi kami ingin membantu para jamaah bisa menjalankan ibadah haji dengan baik.

(Zainut Tauhid Sa'adi, Wakil Menteri Agama, saat menjadi pembicara kunci dalam sebuah webinar.) 


\section{PROPAGANDA}

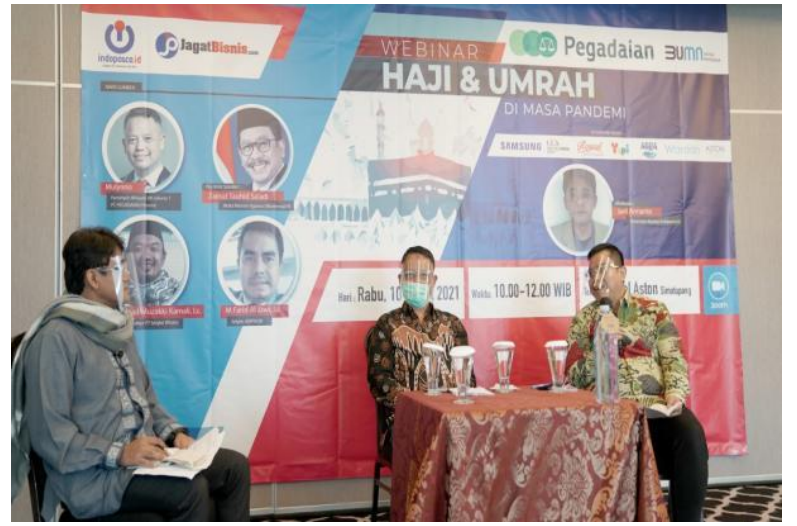

Gambar 1. Diskusi Kemenag dan sejumlah pihak mengenai haji dan umrah

Dalam ungkapan tersebut dapat terlihat bahwa Kementerian Agama terus melakukan peningkatan serta selalu memberikan dukungan terhadap peningkatan dalam pembinaan ibadah haji serta selalu melakukan inovasi-inovasi baru yang mendukung jalan terbaiknya proses ibadah haji dan umrah. Selain itu, diungkapkan pula bahwa pemerintah terus bekerja menyiapkan opsi kuota penuh dengan asumsi kuota normal yang disediakan Arab Saudi.

Semua skenario ini masih sangat tergantung dari pemerintah Arab Saudi. Terakhir menteri agama sudah melakukan komunikasi dengan menteri agama Arab Saudi. Namun masih menunggu, karena kewenangan memberikan ketentuan kepastian haji oleh Raja Arab Saudi.

(Zainut Tauhid Sa'adi, Wakil Menteri Agama)

Meskipun hal tersebut tetap mengeluarkan titik akhir bahwa Indonesia tetaplah masuk dalam salah satu daftar Negara yang dilarang masuk ke wilayah Arab Saudi. Tanggapan itu pula yang menjadikan pemerintah Indonesia mengambil langkah untuk mengeluarkan kebijakan serta putusan bahwa Haji ditiadakan kembali seperti tahun sebelumnya.

Indonesia tidak bisa berbuat banyak lantaran keberangkatan haji tetap menunggu keputusan

Arab Saudi. Ketika kuota itu belum kita dapatkan siapa yang punya otoritas? Kan Arab

Saudi.

(Khorizi, Direktur Jenderal Penyelenggaraan Haji dan Umrah [Dirjen PHU])

Selanjutnya, kelompok civil society dalam hal ini harusnya lebih digaungkan oleh pemerintah. Melihat bahwasanya civil society ini merupakan citra ideal dari sistem kemasyarakatan yang terbaik yang sangat dicita-citakan dalam suatu sistem sosial. Karena proses penyelenggaraan pemerintah yang bersifat tradisional.

Anggota Komisi VIII DPR Bukhori menilai, keraguan masyarakat terkait pembatalan ibadah haji tahun ini dikarenakan kurangnya upaya maksimal dari pemerintah dalam melobi Arab Saudi, hal inilah yang membuat publik mengkritisi kebijakan Kementerian Agama itu.

Selain itu, strategi komunikasi yang dibangun juga tidak mencerminkan dan memperlihatkan kepentingan terorganisir yang baik. Kebijakan serta penerapan untuk tidak dapat meyakinkan Arab.

Itu sebenarnya bisa dimainkan secara maksimal, kalau itu kemudian hal-hal itu sudah dilakukan secara maksimal, tafsir-tafsir jalanan itu pasti tidak akan hadir.

(Bukhori) 
Dikutip dalam keterangan resmi Kementerian Agama, Senin (16/11/2020) bahwa Plt Dirjen Penyelenggaraan haji dan Umrah Kementerian Agama Oman Fathurrahman mengatakan penghentian sementara proses visa dikarenakan pemerintah Arab Saudi sedang melakukan evaluasi dan pengaturan terhadap penyelenggaraan ibadah umrah.

Saat ini pemerintah Arab Saudi sedang menutup proses visa dalam rangka melakukan evaluasi dan pengaturan terhadap penyelenggaraan ibadah umrah bagi jemaah Indonesia. (Oman Fathurrahman, Plt Dirjen Penyelenggaraan Haji dan Umrah Kementerian Agama)

Kabid Umrah Amphuri, Zaky Zakaria Anshary pada Rabu, 3 Februari 2021 menuturkan lewat Tempo.co sebagai berikut.

Saya sangat prihatin dengan pengumuman ini, padahal penyelenggara umrah atau PPIU sedang semangat-semangatnya promosi program umrah dan mempersiapkan keberangkatan umrah setelah kerajaan Arab Saudi memberikan syarat umur menjadi 18 60 pada tanggal 22 Januari 2021.

Selain Zaky, Wakil Ketua DPP Asita Bidang Kelembagaan Pemerintah, Dede Firmansyah pada Minggu, 7 Februari 2021 mengungkapkan sebagai berikut.

Ini yang menjadi perhatian kami di Asita Pusat, di saat perjalanan umrah baru berjalan tiga bulan terakhir, kini di Februari sudah berhenti total. Tolong pemerintah menjadikan ini perhatian khusus.

Meski demikian, dikutip dari dw.com bahwa, Menteri Agama Yaqut Cholil Qoumnas mengatakan bahwa pembatalan atas keberangkatan haji 2021 merupakan keputusan yang sangat sulit meskipun termasuk putusan yang terbaik, seperti yang disampaikannya berikut.

Kami menyadari atas keputusan ini, pasti ini dirasakan sebagai keputusan yang pahit. Tapi kami meyakini inilah keputusan yang terbaik karena sudah melalui kajian yang sangat mendalam.

Terkait hal tersebut, pihak Arab Saudi pun memberi tanggapan soal keputusan Indonesia yang tidak memberangkatkan jemaah haji 2021, Esam Abid Altaghafi selaku Duta Besar Arab Saudi untuk Indonesia mengatakan :

Ketika pemerintah Indonesia atau Menteri Agama Indonesia memutuskan untuk tidak menyelenggarakan haji, kami sangat menghargai keputusan Indonesia.

Selain itu, dikutip dari CNBC Indonesia, bahwasanya Ketua DPP Asosiasi Muslim Penyelenggaraan Haji dan Umrah Republik Indonesia (AMPHURI), Bungsu Sumawijaya, mengatakan bahwa kita perlu melobi kerajaan Arab Saudi untuk memperbolehkan jemaah dari Indonesia masuk ke Arab Saudi.

Pemerintah kita perlu melobi kerajaan Arab, memperbolehkan jemaah kita dari vaksin itu yang disetujui WHO. Mungkin kalau haji ini sulit karena waktunya mepet dua bulan lagi penyelenggaraannya, tapi paling tidak kan untuk umrah boleh masuk.

Sementara itu Pauline Suharno selaku Sekretaris Jenderal Asosiasi Travel Agent Indonesia, mengatakan secara umum banyak travel agent termasuk biro umrah yang memilih pasar lain selain umrah bahkan ada beberapa yang menutup operasionalnya.

Seperti ke Turki sudah boleh masuk, ada juga yang ke Mesir, Maroko, Uzbekistan. Karena pada dasarnya usaha travel ini palugada melihat peluang yang ada. 


\section{PROPAGANDA}

Hal seperti itulah yang menjadikan banyaknya diversifikasi bisnis akan biro perjalanan umrah. Ini semua dilakukan dengan cara menjual produk-produk dari Arab seperti agen asuransi, kurma dan lainnya. Bahkan dari catatan yang dimiliki oleh Pauline Suharno, banyak biro perjalanan yang mati suri hingga tutup. Dalam hal ini maka sangat diperlukan kebijakan dan strategi yang sangat intens antara pemerintah Indonesia dengan pemerintah Arab Saudi. Terlepas dari adanya beberapa pendapat yang tujuan untuk mendesak pemerintah. Karena sebelumnya Indonesia dengan Arab Saudi memiliki keterikatan yang amat dekat. Di luar itu semua, harus adanya evaluasi dengan catatan mengapa Indonesia masih masuk ke dalam daftar nama Negara yang masih belum bisa memasuki wilayah Arab Saudi. Berbeda dengan 11 negara yang sebelumnya merasakan hal yang sama namun penangguhan tersebut dicabut oleh pemerintah Arab Saudi.

\section{PENUTUP}

Adanya Covid-19 memang menjadi sebuah kejutan tersendiri bagi seluruh penduduk dunia. Tidak hanya berdampak besar di bidang kesehatan, namun juga berdampak pada semua sisi kehidupan, seperti ekonomi dan utamanya terhadap sebuah hubungan antar Negara. Untuk itu, perlu di ambil beberapa pelajaran berharga dari hadirnya pandemi Covid-19 ini bahkan yang sampai saat ini masih belum bisa teratasi.

Davis dalam kerangka teorinya juga mampu mengeksplorasi area yang kurang tar wakil terhadap masyarakat sipil, kepentingan terorganisir, dan proses kebijakan dalam penelitian ini. Otorisasi dan legitimasi publik juga yang lebih besar serta kekuasaan atas pengaturan agenda, pembuatan bingkai, dan hasil kebijakan menjadi penting. Akhirnya, jelas bahwa jumlah dan jenis kepentingan terorganisir telah berkembang pesat dalam beberapa dekade. Peluang mereka untuk intervensi juga meningkat. Ada sistem pararel organisasi masyarakat sipil, jaringan dan bentuk komunikasi yang berdampak di semua tingkatan.

Karena sampai saat ini Indonesia masih menjadi salah satu Negara yang masih ditangguhkan kedatangannya untuk berkunjung ke Arab Saudi. Dengan maksud memutus mata rantai penyebaran Covid-19. Padahal di sisi lain, terdapat 11 negara yang akhirnya dicabut penangguhannya untuk berkunjung ke Arab Saudi. Yaitu, Uni Emirat Arab, Jerman, Amerika Serikat, Irlandia, Italia, Portugal, Inggris, Swedia, Swiss, Perancis, dan Jepang. Ke 11 negra tersebut sebelumnya juga masuk ke dalam daftar nama Negara yang dilarang masuk wilayah Arab Saudi.

Framing media terkait strategi Kementerian Agamalah yang menjadi sorotan, khususnya Republika.co.id yang menyorot beberapa poin yang mulai ditetapkan oleh pemerintah untuk masyarakat Indonesia yang hendak melakukan perjalanan haji dan umrah. Indonesia tengah melakukan komunikasi intensif dengan empat maskapai yang terkait dengan Jemaah umrah dan haji, yaitu Garuda, Saudia, Lion, dan Citilink. Saat dibukanya kembali akses umrah awal tahun kemarin oleh pemerintah Arab Saudi, terdapat sekitar 75 orang jamaah umrah Indonesia teridentifikasi Covid-19 ketika mendarat di Arab Saudi saat masa karantina. Hal ini pulalah yang menjadi salah satu faktor Indonesia masih masuk dalam 20 daftar Negara yang dilarang untuk melakukan ibadah haji dan umrah. Tahun 2021 merupakan kali kedua masyarakat Indonesia tidak bisa melakukan ibadah haji.

Hal inilah yang pada akhirnya menimbulkan pro kontra terhadap munculnya larangan bahwa Indonesia masih masuk sebagai Negara yang dilarang masuk wilayah Arab Saudi. Padahal 11 negara yang kini telah dicabut penangguhannya ada yang angka Covid-19 sama bahkan lebih tinggi penularannya dengan Indonesia. Karena sebelumnya Indonesia dengan Arab Saudi memiliki keterikatan yang sangat erat antar Negara. Bahkan Indonesia termasuk Negara yang banyak mengirim jemaah haji dan umrah di setiap tahunnya. 
Sehingga membuat para Asosiasi semua memilik harapan, presiden dalam hal ini Kementerian Agama selaku penyelenggara pemerintahan, dalam membuat kebijakan sebaiknya jangan hanya mempertimbangkan apakah isu tersebut telah mencapai tingkat kritis sehingga tidak bisa diabaikan, apakah isu tersebut sensitif, apakah isu tersebut menyangkut aspek tertentu, apakah isu tersebut menyangkut banyak pihak sehingga mempunyai dampak yang luas dalam masyarakat kalau diabaikan, apakah isu tersebut berkenaan dengan kekuasaan dan legitimasi, dan apakah isu tersebut berkenaan dengan kecenderungan yang sedang berkembang dalam masyarakat. Akan tetapi alangkah baiknya, buatlah kebijakan yang memang sangat dibutuhkan masyarakat tanpa pandang bulu dan banyak pertimbangan dan memang langsung bersentuhan dengan kepentingan masyarakat.

Karena, sesungguhnya setiap kebijakan dan strategi komunikasi yang tidak baik, akan membuat pelaksanaan umrah tidak searah dengan Arab Saudi. Hal ini berdampak Indonesia masih masuk dalam negara yang dibatasi akses ke Arab Saudi. Selain itu, melalui penelitian ini, peneliti menemukan bahwa, pada akhirnya peneliti menemukan beberapa hal penting di dalamnya. 1) Kebijakan Kementerian Agama belum sejalan dengan kebijakan pemerintah Arab Saudi. 2) Saran serta masukan dari asosiasi pemilik organized interest kurang dapat sambutan baik. 3) The policy proces terkesan tergesa-gesa sehingga melahirkan sebuah kebijakan yang tidak tepat an kurang ampuh. 4) Pemerintah dalam hal ini juga kurang melibatkan kelompok civil society secara maksimal. 5) Media yang harusnya menajdi saluran komunikasi belum dijadikan sebagai sebuah saluran yang efektif antara power dan society.

Selain hal tersebut, framing dari media merupakan cara yang paling ampuh untuk menggiring opini pembacanya, baik dari cara memberitakan maupun menjelaskan isi dari berita tersebut yang menyangkut pernyataan, narasumber serta data dan fakta yang dipaparkan untuk dijadikan sebuah konsumsi oleh masyarakat, utamanya media online yang merupakan salah satu media yang paling banyak digunakan oleh sebagian besar masyarakat dunia bahkan Indonesia.

\section{DAFTAR PUSTAKA}

Arifin, A. (2003). Komunikasi Politik, Paradigma-Teori-Aplikasi-Strategi dan Komunikasi Politik Indonesia. Jakarta: Balai Pusata.

Azra, A. (1996). Pergolakan Politik Islam, dari Fundamentalisme, Modernisme Hingga PostModernisme. Jakarta: Paramadina.

Bakti, A. F. (2000). Communication Parallels in the Inluence of Religious Values in the Development of Japan and Indonesia. Review of Human Factor Studies, 6 (1), 1-32.

Bakti, A. F. (2000). Major Conflicts in Indonesia: How Can Communication Contribute to a Solution. Review of Human Factor Studies, 6 (1), 35-50.

Bakti, A. F. (2004). Paramadina and its Approach to Culture and Communication: An Engagement in Civil Society. Archipel, 68 (1), 315-341.

Bakti, A. F. (2005). Islam and Modernity: Nurcholish Madjid's Interpretation of Civil Socity, Pluralism, Secularization, and Democracy. Asian Journal of Social Science, 33 (3), 486-505.

Bakti, A. F. (2006). Majelis Azikra: New Approach to Dakwah for Civil Society in Indonesia," Dalam Mimbar Agama dan Budaya.

Bakti, A. F. (2006). Daarut Tauhiid: New Approach to dakwah for Peace in Indonesia. Jurnal Kajian Dakwah dan Komunikasi. 08 (1), 1-29.

Bakti, A. F. (2008). Communication and Violence: Communicating Human Integrity Characteristics is Necessary of Horizontal Conflict Resolution in Indonesia. Identity, Culture \& Politics: An Afro-Asian Dialogue. 06 (1), 11-74. 


\section{PROPAGANDA}

Bakti, A. F. (2011). The Role of Islamic Media in the Globalization Era: Between Religious Principles and Values of Globalization, The Challenges and the Opportunities. The Second International Conference on Islamic Media, 13-15.

Bakti, A. F. (2013). Raising Public Consciousness About the Importance of Freedom of Expression in Democratic Society and on Enhancing the uality of Life of the Ordinary Citizen: the Case of Indonesia. The Journal of Development Communication, 24 (1),0114.

Bakti, A. F. dan Isabelle Lecomte (2015). The Integration of Dakwah in Journalis: Peace Journalism. Jurnal Komunikasi Islam, 05 (1), 185-203.

Bennet,W.L. (2016). Toward a Theory of Press-State Relations in the United States. Journal of Communication, 40 (2): 103-25.

Beyers, J., Eising, R. and Maloney, W. (2008). Researching Interes Group Politics in Europe and Elsewhere: Much We Study, Little We Know. Western European Politics, 31 (6): 1103-28.

Blumler, J. G., Blumler, J., \& Gurevitch, M. (1995). The crisis of public communication. Psychology Press.Hovland, C. I., Janis, I. L., \& Kelley, H. H. (1983). Communication and persuasion. New Haven: Yale University Press.

Cairney, P. (2016). The Politics of Evidence Based Policymaking. London: Palgrave

Cerny, P., Menz, G. and Soderberg, S (2005). Different Roads to Globalization NeoLiberalism, the Competition State, and Politics in a More Open World' in Soderberg.

Cerny, G. eds. Internalizing Globalization: The Rise of Neo-Liberilsm and the Decline of National Varieties of Capitalism, Houndsmill, Basingstoke: Palgrave Macmillan, pp. $1-30$.

CNBC Indonesia. (2021). Haji \& Umrah 2021 'Gantung', RO Didesak Lobi Arab Saudi. https://www.cnbcindonesia.com/news/2021062152020-4-250052/haji-umroh-2021gantung-ri-didesak-lobi-arab-saudi

Copenhagen Economics (March 2020). Economic Consequences of the Covid-19 Pandemic. https://www.copenhageneconomics.com/dyn/resources/Publication/publicationPDF/0 1530/1585835646/copenhagen-economics_economic-consequences-covid-19.pdf

Cronin, A (2018). Public Realtions Capitalism: Promotional Culture, Publics and Commercial Democracy, Basingstoke. Palgrave Macmillan.

Crouch, C (2011). The Strange Npn-Death of Neo-Liberalism. Cambridge: Polity.

Dahl, R. (1971). Polyarchy: Participation and Opposition. Chealse: Yale University Press

Davis, A. (2019). Political Communication: A New Introduction for Crisis Times. John Wiley \& Sons, Ltd.

Davis, A. and Khiabany, G. (2020). Media, Democracy and Social Change: Re-imagining Political Communications. Sage.

Davis, A. (2013). Promotional Cultures: The Rise and Spread of Advertising, Public Relations, Marketing and Branding. Cambridge:Polity.

Davis, A. (2019). Political Communication, A New Introduction for Crisis Times, Cambridge: Polity Press.

Della, P. D. and Diani, M. (2015). 'Introduction: The Field of Social Movement Studies' in Della Porta, D. and Diani, M. eds. The Oxford Handbook of social Movement. Oxford:Oxford University Press.

Domhoff,G. (1967). Who Rules America? Englewood Cliffs, NJ:Prentice-Hall.

Dunleavy,P. and O'Leary,B. (1987). Theories of the State. London:Macmillan. Edge of Corporate Power, London: Pluto Press.

Eriyanto. (2005). Analisis Framing : Konstruksi, Ideologi, dan Politik Media. Yogyakarta : LKiS.

Fenton, N. (2020). Indymedia and the long story of rebellion against neoliberal capitalism. 
Media, Culture \& Society, 42(6), 1052-1058.

Fletcher, F., \& Young, Mary Lunn. (2012). The Sage Handbook of Political Communication. London: Sage Publications Ltd.

ILO. (2020). Kebijakan Perlindungan Sosial dalam Merespons Krisis Covid-19: Respon Negara-negara di Asia dan Pasifik. Spotlight Brief. ILO:Geneva.

IMF. (2020). "A Crisis Like No Other, An Uncertain Recovery". World Economic Outlook Update.

Jones, P. K. (2021). Demagogic populism and media system: A preliminary articulation. European Journal of Communication, 0267323121999532.

Kaldor,M., Moore, H. and Selchow, S. eds. (2012). Global Civil Society 2012: Ten Years of Critical Reflection. Basingstoke: Palgrave Masmillan.

Kelly, Ann H., and McGoey, Lisney. (2018). "Facts, Power and Global Evidence: A New Empire of Truth," Economy and Society, Vol. 47, No. 1.

Kemenag. (2021. Maret 10). Covid 19 Masih Tinggi, Saudi Berlakukan Umrah Secara Terbatas. https://haji.kemenag.go.id/v4/covid-19-masih-tinggi-saudi-berlakukanumrah-secara-terbatas.

Koc-Michalska, K., \& Lilleker, D. (2017). Digital politics: Mobilization, engagement, and participation. Political Communication, 34(1).

Konwles, S., Phillips, G. and Lidberg, J. (2017). 'Reporting the Global Financial Crisis: A Longitudinal Tri-Nation Study of Mainstream Financial Journalism', Journalism Studies, 18 (3): 322-40.

Lindblom,C. (1977). Politics and Markets: The World's Political Economics Systems, New York: Basic Books

Lin, Zhixian and Meissner, Cristopher M. (2020). Health Wealth? Publik Health Policies and The Economy During Covid-19. NBER Working Paper No.27099

Lukes, S. (2005). Power: A Radical View, 2nd edn, Basingstoke: Palgrave Macmillan.

Mabruroh. (2020). Arab Saudi Batasi Jamaah Haji Kurang dari 1000 Orang. https://ihram.co.id/berita/qcekad459/arab-saudi-batasi-jemaah-haji-kurang-dari-1000orang

Macnamara, J. (2021). Challenging post-communication: Beyond focus on a 'few bad apples' to multi-level public communication reform. Communication Research and Practice, 121.

Maharani, T. (2020). Ketua MPR: Pemerintah Pusat dan Daerah Harus Koordinasi JIka Longgarkan PSBB. https://nasional.kompas.com/read/2020/05/13/14422921/ketuampr-pemerintah-pusat-dan-daerah-harus-berkoordinasi-jika-longgarkan-psbb

Mair, P, (2013), Ruling the Void: The Hollowing of Western Democracy, London:Verso.

Malau, Y. (2014). "Implementasi Sistem Pelayanan Pendaftaran Haji dan Umrah Online pada Pt. Mandiri Mawassah Nusantara. Jurnal Bianglala Informatika, Vol. 10, No. 1.

Manski, C. (2011). "Policy Analysis with Incredible Certitude," Economic Journal, Vol. 121, No. 54.

Marchand, R. (1998). Creating the Coporate Soul, Berkeley, LA: University of California Press.

Mas'udi, W dan Winanti, P. S. (2020). (eds). Tata Kelola Penanganan Covid-19 di Indonesia: Kajian Awal. Yogyakarta: Gadjah Mada University Press

Miliband, R. (1969). The State in Capitalist Society, London:Weidenfeld and Nicolson Miller, D. and Dian, W. (2008) A Century of Spin: How Public Relayions Became the Cutting.

Mills, C. Wright (1956). The Power Elite, Oxford: Oxford University Press.

Mirowski, P. and Plehwe, D. eds. (2009), The Road from Mont Pelerin: The Making of the Neoliberal Thought Collective, Cambridge, MA: Harvard University Press.

Misrawi, Zuhairi. (2021). Kokohnya HUbungan Indonesia-Arab Saudi, Diakses pada 22 Mei 


\section{PROPAGANDA}

2021, Pukul 9:36 WIB. Pada https://news.detik.com/kolom/d-5481336/kokohnyahubungan-indonesia-arab-saudi

Mizrichi, M. (2013). The Fracturing of the American Corporate Elite, Cambridge, MA: Harvard University Press.

Moko, M. (2021, April 17). Masih 'Suspended Temporary', Jamaah Umrah RI Belum Bisa Masuk Arab Saudi. https://www.suaramerdeka.com/news/nasional/261015-masihsuspended-temporary-jamaah-umrah-ri-belum-bisa-masuk-arab-saudi

Naim, M. (2013). The End of Power: From Boardrooms to Battlefields and Churches to States.

Offe, C. (1984). Contradictions of the Welfare State (ed. Keane,J.) Cambridge, MA: MIT Press.

Oliver, S. (2006). Strategi Public Relations, London: PT. Gelora Aksara Pramata.

Philo, G. (1995), Glasgow Media Group Reader, Vol. 2: Industry, Economy, War and Politics, London: Routledge.

Prastiwi, D. (2021). 8 Pertanyaan Menag Yaqut soal Batalnya Keberangkatan Jemaah Haji 2021. https://m.liputan6.com/news/read/4573206/8-pertanyaan-menag-yaut-soalbatalnya-keberangkatan-jemaah-haji-2021

Putra, E. P. (2021). Daftar 11 Negara yang Diperbolehkan Masuk Arab Saudi. https://www.google.com/amp/s/m.republika.co.id/amp/u5fhj484

Rakhmat, J. (2004). Metode Penelitian Komunikasi . Bandung : PT Remaja Rosdakarya

Republika. (2021, April 3). Larangan Masuk Arab Saudi Sudah Diprediksi Pengusaha Travel. https://republika.co.id/berita/jurnal-haji/berita-jurnal-haji/qnyb4t320/larangan-masukarab-saudi-sudah-diprediksi-pengusaha-travel

Reuters (2017). Reuters Institute Digital News Report, Oxford: Reuters Institute for the Study of Joutrnalism.

Schattschneider, E.E. (1961). The Semi-Sovereign People: A Realist's View of Democracy in America, New York: Holt, Rinehart and Winston.

Sobur, Alex. (2002). Analisis Teks Media: Suatu Pengantar Untuk Analisis Wacana, Analisis dan Framing. Bandung: PT Remaja Rosdakarya.

Sugiyono. (2012). Memahami Penelitian Kualitatif, Bandung: Alfabeta.

Sugiyono. (2014). Metode Penelitian Kuantitatif, Kualitatif dan R\&D, Bandung: Alfabeta.

Sussman, G. (2011). The Propaganda Society: Promotional Culture and Politics in Global Context, New York: Peter Lang. Gramedia.

Why Being in Change Isn't What is Used to Be, New York: Basic Books.

Wheelen, Thomas L., Hunger, J. David. (2010). Strategic Management and Business Policy Achieving Sustainability. Twelfth Edition. Pearson.

Yezli dan Khan. (2020). "COVID-19 Social Distancing in the Kingdom of Saudi Arabia: Bold Measures in the Face of Political, Economic, Social and Religious Challenges. 